\title{
"In vitro" evaluation of the bacterivore potential of three Cladoceran species occurring in tropical and subtropical regions
}

\author{
L. H. Hayashi-Martins ${ }^{a}$, A. S. Mansano ${ }^{a}$, K. F. Hisatugo ${ }^{a}$, O. Rocha ${ }^{b}$ and M. H. R. Seleghim ${ }^{a}$
}

aLaboratório de Ecologia de Microrganismos Aquáticos - LEMA, Departamento de Ecologia e Biologia Evolutiva DEBE, Universidade Federal de São Carlos - UFSCar, Rodovia Washington Luís, SP 310, Km 235, CEP 13565-905, São Carlos, SP, Brazil

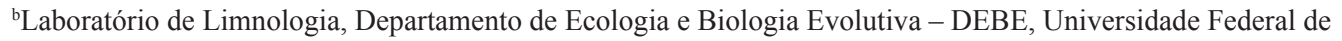
São Carlos - UFSCar, Rodovia Washington Luís, SP 310, Km 235, CEP 13565-905, São Carlos, SP, Brazil

*e-mail: luhayashi@yahoo.com.br

Received: March 3, 2016 - Accepted: June 10, 2016 - Distributed: November 31, 2017

(With 4 figures)

\begin{abstract}
Cladocerans occupy an important position among the bacterial consumers in freshwater food webs, being relatively non-selective filter feeders that can exert a strong impact on microbial populations. We evaluated the bacterivory potential of three cladocerans species of subtropical and tropical occurrence (Ceriodaphnia silvestrii, Daphnia gessneri and Ceriodaphnia cornuta) at different life stages, by scanning electron microscopy (SEM) and by the quantification of their bacterial consumption rates using fluorescently labeled bacteria (FLB). All species showed filter mesh sizes sufficiently narrow to retain bacteria. The largest distance between setules was found in primiparous $C$. cornuta, and the smallest in neonate $D$. gessneri. The lowest ingestion (IR) and removal (RR) rates were observed in primiparous C. silvestrii and the highest values were observed in adults of $D$. gessneri. We conclude that bacteria may be considered an important food supplement, particularly for neonates who presented smaller intersetular distances and higher filtration rates than the other life stages.
\end{abstract}

Keywords: SEM, bacterivory, FLB, Daphnia, Ceriodaphnia.

\section{Avaliação "in vitro" do potencial baterívoro de três espécies de Cladocera de ocorrência tropical e subtropical}

\section{Resumo}

Dentre os diversos consumidores de bactérias nas teias alimentares de ambientes dulcícolas, os cladóceros ocupam uma posição relevante, sendo filtradores relativamente não seletivos que podem exercer forte impacto na redução populacional microbiana. Avaliamos o potencial bacterívoro de três espécies de cladóceros de ocorrência tropical e subtropical (Ceriodaphnia silvestrii, Ceriodaphnia cornuta e Daphnia gessneri) em diferentes fases de vida, através do estudo microscópico de suas estruturas filtradoras e da quantificação de suas taxas de ingestão em experimentos de bacterivoria utilizando-se bactérias marcadas fluorescentemente (FLB). As espécies estudadas mostraram ter uma rede de malhas filtradoras suficientemente estreitas para reter bactérias. A maior distância entre as sétulas foi encontrada em primíparas de C. cornuta, e a menor em neonatos de D. gessneri. As menores Taxas de Ingestão (TI) e Remoção (TR) foram observadas em primíparas de $C$. silvestrii e as maiores em adultas de D. gessneri. Concluímos que as bactérias podem ser consideradas um importante suplemento alimentar, principalmente para neonatos, que apresentaram pequenas distâncias intersetulares e altas taxas de ingestão comparadas aos outros estágios de vida.

Palavras-chave: MEV, bacterivoria, FLB, Daphnia, Ceriodaphnia.

\section{Introduction}

The cladocerans are among the most common organisms that make up the zooplankton. Although it is known that the planktonic cladoceran species feed on algae, bacteria and other particulate matter (Rocha et al., 2011), their food-gathering mechanisms are still unclear (Brendelberger, 1991) and the minimum size of particles that can be efficiently filtered by each individual species is unknown. Thus, it is not possible to quantitatively assess the overall significance of cladocerans food consumption for the planktonic food web (Geller and Müller, 1981).

While exploring a wide variety of foods, cladocerans are traditionally considered as algivores. Numerous studies 
have evaluated the quality of several algae species as food in the daphnids diet (Arnold, 1971; Porter and Orcutt, 1980; Kilham et al., 1997), but few have considered the role of alternative food sources, such as bacteria or protozoa (DeBiase et al., 1990; Freese and Martin-Creuzburg, 2013).

Among the large cladocerans, Daphnia became a model for studies on the "top-down" control effects in microbial food webs, since it acts as a predator capable of triggering a trophic cascade by removal of large aggregates, bacterial communities and heterotrophic nanoflagellates (Langenheder and Jürgens, 2001; Degans et al., 2002; Pernthaler, 2005; Lampert, 2006).

As food particles are retained in the cladocerans filtration apparatus, detailed knowledge of their granulometry and mesh structure will allow the prediction of the cladocerans particle retention efficiency. This prediction can then be compared with the results of grazing experiments. If there is no relation between the predicted and the experimental results, other filtration mechanisms must be involved (Brendelberger, 1991).

Several different techniques have been used to record the impacts of predation on bacteria (Langenheder and Jürgens, 2001). These studies assessed the bacterivory potential of protozooplankton (Hahn and Höfle, 2001; Pernthaler, 2005) and metazooplankton (Kim et al., 2000; Langenheder and Jürgens, 2001; Agasild and Nõges, 2005), and were made mostly in temperate and more rarely in tropical environments. From these studies it was obtained most of the knowledge about the aquatic plankton trophic dynamics. It is known, for example, that a number of factors such as species type, body size, nutritional history, water temperature, amount and quality of food, influence, directly or indirectly, cladocerans removal and ingestion rates. So, in order to reduce variability caused by the intake rate of different sized animals, researchers frequently work only with adults (Lampert, 1987).

In this work it was studied the microscopic structure of the filter apparatus of three different sized species of cladoceran daphnids typical of tropical and subtropical environments (Ceriodaphnia silvestrii Daday, 1902; Ceriodaphnia cornuta Sars, 1885 and Daphnia gessneri Herbst, 1967). In parallel, grazing experiments were conducted in the laboratory, aiming to evaluate their bacterivory potential in their different life stages.

\section{Material and Methods}

The cladocerans chosen for the study ( $C$. silvestrii, D. gessneri and C. cornuta) were collected in the Lobo Reservoir - SP, Brazil, in May and July 2009 and January 2011 , through water column vertical hauls, using a $68 \mu \mathrm{m}$ mesh plankton net. The organisms were placed in $600 \mathrm{~mL}$ screw-capped bottles and transported to the laboratory under refrigeration. In the laboratory, the three species of interest were separated from the others, with the aid of Pasteur pipettes, using a stereoscopic microscope, and identified under optical microscopy. The specimens were washed with reconstituted water and placed in beakers containing the reservoir water (three times filtered onto a $45 \mu \mathrm{m}$ pore mesh). The acclimatization was gradual by replacing the reservoir by the reconstituted water, until complete substitution.

For the cladocerans cultivation we followed the standardized norms by ABNT (2005). The organisms were grown in a $2 \mathrm{~L}$ beaker, with reconstituted soft water (total hardness with 40-48 $\mathrm{mg} \mathrm{CaCO}_{3} / \mathrm{L}, \mathrm{pH}$ 7.0-7.6) at $25^{\circ} \mathrm{C}$ under a light: dark photoperiod of $12: 12 \mathrm{~h}$. For stock cultures, the medium was renewed three times a week, maintaining about 120 individuals per beaker for C. cornuta and $C$. silvestrii and 80 for $D$. gessneri. The organisms were fed daily with the green algae Raphydocelis subcapitata from a culture in exponential growth phase $\left(10^{5}\right.$ cells . $\left.\mathrm{mL}^{-1}\right)$ and a suspension made with the mixture of dried baker's yeast (Fleishmann ${ }^{\circledR}$ ) dissolved in distilled water and fermented food fish (Tetramin ${ }^{\circledR}$ ) at a final concentration of $0.02 \mathrm{~mL}$ per organism.

For the scanning electron microscopy analysis of the cladocerans filtration apparatus we used the technique described by Laforsch and Tollrian (2000). Aiming to clean and to facilitate the measurement of these structures, cladocerans from the cultures were left one night without food. The animals were then killed in a microwave oven (4 seconds) and immediately fixed with 70\% ethanol. Dehydration was done in three baths of 10 minutes in $70,80,90,98$ and $100 \%$ ethanol, respectively. The specimens were dissected, and their filtration apparatus fixed on aluminum stubs with double-sided tape. The stub was transferred to a desiccator with silica gel (Merck-Suchardt, Darmstadt) under vacuum and kept there overnight to complete drying and stabilization of the structure. The material was coated in gold and at least two sections of the filtration mesh of each specimen were photographed, specifically from the central area and the base of the setules. Scanning electron microscopy (SEM) was made using a Zeiss DSM-960 and the distances between the central axes of the setules were measured from the micrographs. To calculate the actual width of the mesh, the diameter of the setule was subtracted.

For the bacterivory experiments it were used fluorescently labeled bacteria (FLB) of Escherichia coli ATCC 8739 stained according to Sherr et al. (1987), using the fluorochrome 5 - (4,6-dichlorotriazin-2yl) aminofluorescein (DTAF). The choice of bacterium used as a marker (E. coli ATCC 8739) was based on its size and its shape, which resembles the average shape and size of most of the bacteria found in the cultivation water. The bacterial morphotypes were determined by the length / width ratio, which ranged from $1.23 \mu \mathrm{m}$ to $1.68 \mu \mathrm{m}$. In laboratory testing, the $E$. coli strain used showed a length / width ratio of $1.28 \mu \mathrm{m}$, after fixation. E. coli solid growth was collected with one standard inoculation loop and was inoculated into $40 \mathrm{~mL}$ of synthetic broth and incubated in a shaker at $37{ }^{\circ} \mathrm{C}$. The bacteria were obtained from the log phase of the culture to avoid the formation of agglomerates. Then the culture was centrifuged ( $5410 \mathrm{xg}$ for 5 minutes) and the pellet was resuspended in $10 \mathrm{~mL}$ of sterile phosphate buffered saline ( $\mathrm{pH}$ 9). Subsequently, $2 \mathrm{mg}$ of the dye (DTAF) was added 
to the suspension, which was then heated in a water bath at $60{ }^{\circ} \mathrm{C}$ for 2 hours. After this stage, the cells were again centrifuged and washed three times with $10 \mathrm{~mL}$ of sterile buffered saline. After the last wash, cells were resuspended in $20 \mathrm{~mL}$ of $0.02 \mathrm{M}$ tetrasodium pyrophosphate, which has buffering effect. The suspension was vortexed for 1 minute and aliquots of 1 to $2 \mathrm{~mL}$ were pipetted into cryovials (Eppendorf ${ }^{\circledR}$ ) which were sealed and stored in a freezer. For the bacterivory experiments, the stored FLB were thawed and placed for 1 minute in ultrasonic bath (ultracleaner 1400, Unique brand) in order to discard any clumps. To calculate the FLB concentration used in the experiments, the bacterial density in the sample (culture flask) was estimated according to Porter and Feig (1980). The labeled bacteria were sonicated and diluted in a $0.85 \%$ saline buffer to a concentration of $5 \%$ of the bacterial abundance previously estimated in the sample, than vortexed and added to beakers containing the reconstituted soft water, the cladoceran food and the cladocerans specimens to be tested. For each cladoceran species, we tested several FLB concentrations $(15,10,8,5$ and $3 \%$ ), and the $5 \%$ of the bacterial abundance was more appropriate, because it was possible to visualize the FLB without agglomerates and prevented underestimation in counts due to few quantities of FLB.

The following incubation time intervals were tested: $0,10,20,30 ; 0,5,10,15 ; 0,4,8,12 ; 0,3,6,9$ and $0,2,4,6$ minutes. The FLB / cladoceran during the incubation intervals were plotted in a graph. The stabilization and / or decline of the curve after the peak mean digestion / egestion of the bacteria. The incubation times considered most appropriate and used as standard for all experiments were: $0,2,4$ and 6 minutes.

After each incubation time, the daphnids were filtered through a $10 \mu \mathrm{m}$ mesh net, anesthetized with $10 \mathrm{~mL}$ mineral water Schincariol ${ }^{\circledR}$, for preventing evacuation of intestinal contents, and fixed with $4 \%$ formalin solution. Then, they were washed with sterile distilled water, dissected to remove the shell carefully avoiding digestive system damage and placed onto a black polycarbonate membrane of $10 \mu \mathrm{m}$ pore diameter. The membranes were then placed between slide and coverslip, using a non-fluorescent immersion oil (Cargille $\left.{ }^{\circledR}\right)$, top pressed lightly and analyzed using an epifluorescence microscope Olympus BHS-313, equipped with a HBO 200 mercury lamp. The specimens were observed under blue light at 1,250X magnification for counting the FLB inside the digestive system. To each sample it was analyzed all the digestive tract of at least 15 individuals.

In all experiments, the species studied were divided into three classes, taking into account its size and lifestage: neonate (born at less than 24 hours), primiparous (age of first reproduction) and adult. So, for each experiment, a new culture was started from stock cultures where the organisms present thereon had the same age, neonates newly hatched collected and placed in a beaker containing water and food cultivation. Growth of the specimens was monitored daily until they reach the desired stage of life.
For the experiments with neonate, gravid females were separated in a beaker, and after the hatching, the adults were removed leaving only the neonate less than 24 hours old in the beakers.

The number of FLB consumed by daphnid during the incubation time was plotted on a graph. The FLB consumption rate by the daphnids (FLB uptake rate) was obtained by the regression of the linear part of the curve. The individual ingestion rate of bacteria $\left(\right.$ bact ind $\mathrm{d}^{-1} \cdot \mathrm{h}^{-1}$ ) by the cladocerans was obtained by multiplying the consumption rate by the ratio between the bacterial density present on the cultivation flasks and the density of FLB added to them. The rate of bacterial removal $\left(\mathrm{nL}\right.$. ind $\left.\mathrm{i}^{-1} \cdot \mathrm{h}^{-1}\right)$ was obtained by dividing the consumption rate by the concentration of FLB nL-1 in the sample. Individual intake rates were multiplied by the number of individuals of each taxon analyzed $\mathrm{mL}^{-1}$ to obtain the population ingestion rate per hour (bact . $\mathrm{mL}^{-1} \cdot \mathrm{h}^{-1}$ ) (Sherr and Sherr, 1991).

All statistical analyzes were performed using the software XLSTAT Pro 2008.

\section{Results}

The largest mean $( \pm \mathrm{SD})$ setules mesh size was found in primiparous $C$. cornuta, with $0.39 \mu \mathrm{m}( \pm 0.17)$, and the smallest was in neonate $D$. gessneri, with $0.11 \mu \mathrm{m}$ $( \pm 0.05)$ (Table 1).

The distance between D. gessneri setules increased with the body size, that's means smaller distances between setules were observed in neonates $(0.11 \mu \mathrm{m} \pm 0.02 \mu \mathrm{m})$, and greater distances $(0.26 \mu \mathrm{m} \pm 0.05 \mu \mathrm{m})$ in adults. This relationship was only observed in this specie. In the other two species, the greater distances between setules were observed in young adults (primiparous).

Regarding the width of setules, neonate $D$. gessneri showed closer setules $(0.12 \mu \mathrm{m})$ compared to adults $(0.24 \mu \mathrm{m})$. As well as the increasing distance between the setules, the increase of the width of setules with increasing body of the organism was only observed in this species. The three species were shown to have setules wider at the base compared to the central part. Therefore, in the base, the spacing between setules is smaller.

In "in vitro" grazing experiments, the average bacterial density found in culture flasks with zooplankton from Lobo Reservoir, acclimated and grown in the laboratory, with usual concentration of food (compound food with algae suspension) was $1.1 \times 10^{6}$ cells. $\mathrm{mL}^{-1}$. The predominant bacterial form found in the flasks was bacillar. The three Cladoceran species studied ingested the labeled bacteria offered, and $96 \%$ of specimens tested had consumed the FLB. The individuals who did not consume FLB were included in the calculations of the ingestion rates (IR) and removal (RR).

The relationship FLB/cladoceran, plotted on a graph by incubation time, showed a linear increase of the relation to a given time. In the species D. gessneri and C. silvestrii, the number of ingested labeled bacteria increased in the 
first two minutes when it reached a plateau, whereas for C. cornuta the plateau was reached at 4 minutes (Figure 1).

Table 2 shows the average sizes (length) and standard deviations of individuals at each life stage (neonate, primiparous and adult). The largest individuals were found in adult $D$. gessneri with an average size of $1.45 \mathrm{~mm}$, and the smallest, in the neonate $C$. cornuta with $0.25 \mathrm{~mm}$.

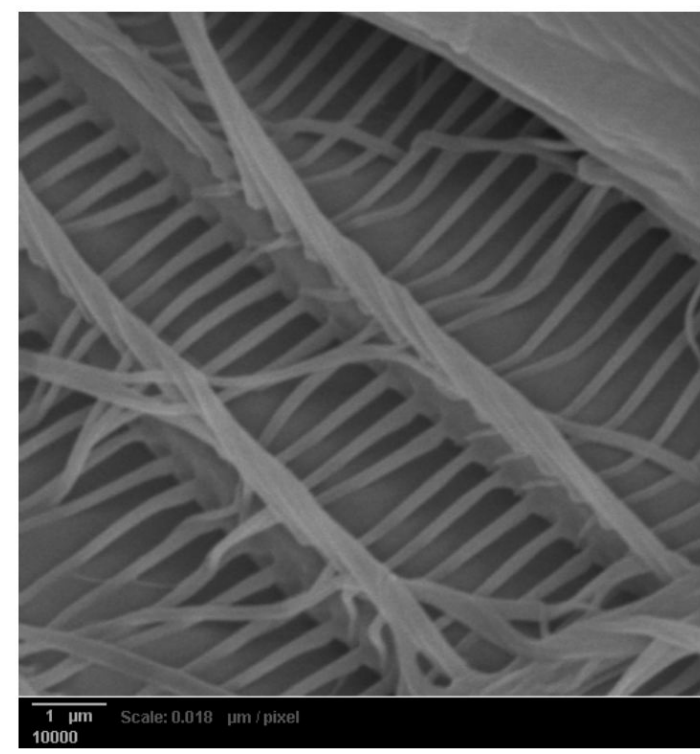

Figure 1. Scanning electron micrograph of individual setules of $D$. gessneri in adult stage. The setules are linked together along the mid-line. Mean diameter of the setules $0.18 \pm 0.02$ $\mu \mathrm{m}$ and mean intersetular distance $0.26 \pm 0.05 \mu \mathrm{m}$. Scalar $9 \mu \mathrm{m}$.
The lowest values found for the rates of ingestion and removal were respectively $1.10 \times 10^{5}$ bact. ind $^{-1} \cdot \mathrm{h}^{-1}$ and $0.10 \mathrm{~mL}$. ind $\mathrm{d}^{-1} \cdot \mathrm{h}^{-1}$ in primiparous of $C$. silvestrii. The highest values were, respectively, $4.40 \times 10^{5}$ bact. ind $^{-1} . \mathrm{h}^{-1}$ and $0.40 \mathrm{~mL}$. ind $\mathrm{d}^{-1} \cdot \mathrm{h}^{-1}$ observed in D. gessneri adult (Figures 2 and 3).

Neonates of all studied species showed relatively high rates of filtration. Neonate $C$. silvestrii and $C$. cornuta showed filtration rates higher than those found for primiparous. Filtration rates of neonate $C$. silvestrii were also higher than those found for adults of this species.

\section{Discussion}

The three studied species demonstrated to have a filter mesh size sufficiently narrow to retain bacteria. The minimum size of particles that can be used as food for cladocerans is important to determine their role in the aquatic food webs. Based on the filter mesh size, Geller and Muller (1981) divided the cladoceran species as "high efficiency bacterial consumers", those that have fine mesh (2.24 to $0.64 \mu \mathrm{m})$; "low efficiency bacterial consumers", those which have average mesh size (1.0 to $1.6 \mu \mathrm{m})$; and "macrofiltrating", those who have coarse filter meshes (finer than $2 \mu \mathrm{m}$ only in a small part of the filtration apparatus) and are unable to feed bacterial cells in suspension. In this classification, the three studied species in our work are considered as high efficiency bacterial consumers because they possess fine meshes. The highest intersetular distance average was found in primiparous of $C$. cornuta $(0.39 \mu \mathrm{m})$, and the lowest intersetular distance average in neonate of D. gessneri $(0.11 \mu \mathrm{m})$.

Table 1. Mean distances $(\mu \mathrm{m})$ and \pm SD between setules, setules width, distance between the base setules and the base setules width. Four individuals of each species were analyzed. For each individual, it was taken 4 measurements at each life stage.

\begin{tabular}{|c|c|c|c|c|c|c|c|c|c|}
\hline & & $\begin{array}{c}\text { Distance } \\
(\mu \mathrm{m})\end{array}$ & $\pm \mathbf{S D}$ & $\begin{array}{l}\text { width } \\
(\mu \mathrm{m})\end{array}$ & $\pm \mathbf{S D}$ & $\begin{array}{c}\text { Distance } \\
\text { (base) } \\
(\mu \mathrm{m})\end{array}$ & \pm SD & $\begin{array}{c}\text { width } \\
\text { (base) } \\
(\mu \mathrm{m})\end{array}$ & \pm SD \\
\hline \multirow[t]{3}{*}{ D.gessneri } & Neonate & 0.11 & 0.02 & 0.12 & 0.02 & 0.15 & 0.03 & 0.15 & 0.02 \\
\hline & primiparous & 0.24 & 0.03 & 0.13 & 0.01 & 0.24 & 0.01 & 0.16 & 0.02 \\
\hline & Adult & 0.26 & 0.05 & 0.18 & 0.02 & 0.24 & 0.02 & 0.25 & 0.01 \\
\hline \multirow[t]{3}{*}{ C.silvestrii } & Neonate & 0.16 & 0.04 & 0.09 & 0.01 & 0.16 & 0.01 & 0.15 & 0.01 \\
\hline & primiparous & 0.18 & 0.05 & 0.1 & 0.01 & 0.14 & 0.01 & 0.17 & 0.01 \\
\hline & Adult & 0.15 & 0.06 & 0.13 & 0.02 & 0.13 & 0.02 & 0.17 & 0.02 \\
\hline \multirow[t]{3}{*}{ C.cornuta } & Neonate & 0.33 & 0.03 & 0.14 & 0.06 & 0.24 & 0.03 & 0.24 & 0.01 \\
\hline & primiparous & 0.39 & 0.17 & 0.14 & 0.01 & 0.22 & 0.04 & 0.21 & 0.03 \\
\hline & Adult & 0.13 & 0.01 & 0.11 & 0.01 & 0.12 & 0.03 & 0.12 & 0.03 \\
\hline
\end{tabular}

Table 2. Mean length of individuals $(\mathrm{mm})$ and standard deviations of the three species in different tested life stages.

\begin{tabular}{cccc}
\hline \multirow{2}{*}{ Life stage } & \multicolumn{3}{c}{ Length $(\mathbf{m m})$} \\
\cline { 2 - 4 } & D.gessneri & C.silvestrii & C.cornuta \\
\hline Neonate & $0.680 \pm 0.025$ & $0.367 \pm 0.023$ & $0.259 \pm 0.009$ \\
Primiparous & $1.029 \pm 0.078$ & $0.557 \pm 0.036$ & $0.429 \pm 0.007$ \\
Adult & $1.454 \pm 0.088$ & $0.858 \pm 0.056$ & $0.594 \pm 0.017$ \\
\hline
\end{tabular}



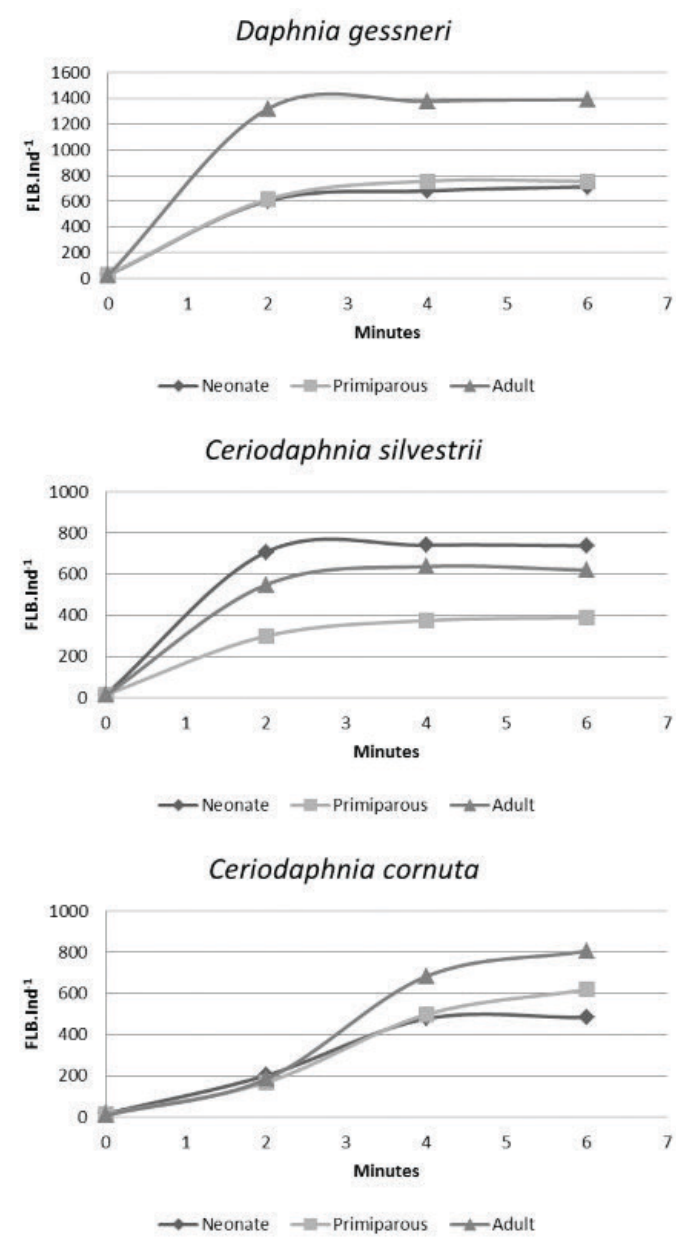

Figure 2. Fluorescently labeled bacteria (FLB) uptake as a function of time in different life stages of $D$. gessneri, C. silvestrii and C. cornuta.

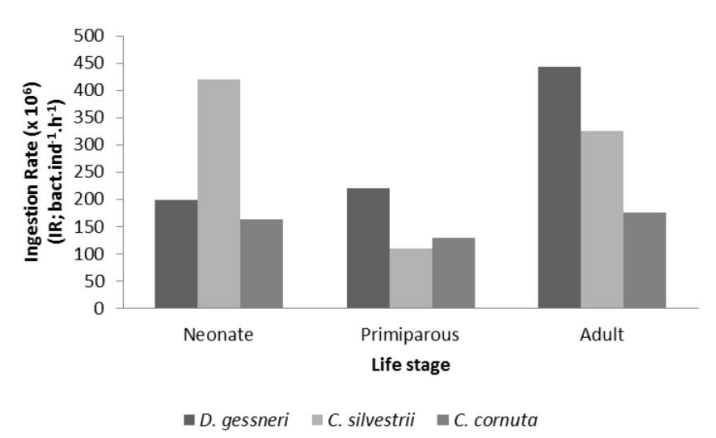

Figure 3. Ingestion Rate (IR, FLB.individual ${ }^{-1} \mathrm{~h}^{-1}$ ) of D. gessneri, C. silvestrii and C. cornuta at different life stage.

The distance between the setules of the D. gessneri increased with the body size as well as with the setules width. According to Brendelberger (1991), in the same species, particulate retention is lower in adults in comparison with juvenile forms because they have wider mesh filters.

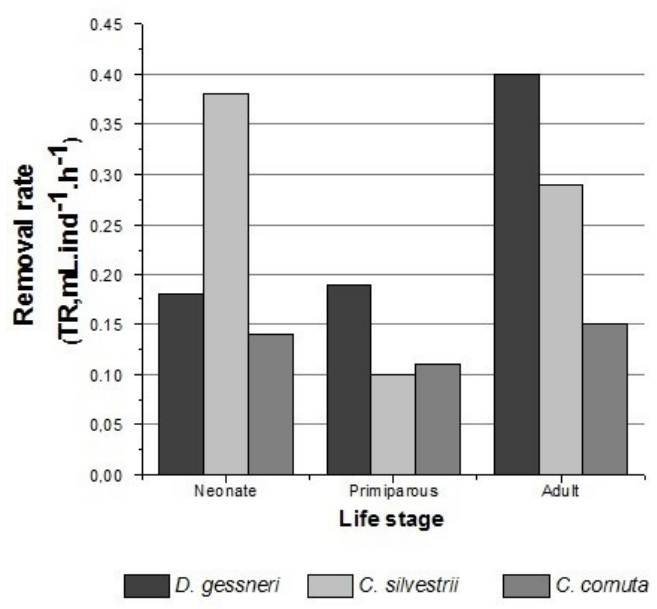

Figure 4. Removal Rate (RR, mL.individual ${ }^{-1} \mathrm{~h}^{-1}$ ) of D. gessneri, C. silvestrii and C. cornuta at different life stage.

However, we do not observed the same for the other two studied species. Adults, primiparous and neonates of $C$. silvestrii have pretty much the same spacing between setules and C. cornuta neonates have larger ones compared to adults. The filter apparatus, feeding habits, and / or nutritional requirements may differ in neonates from the other life stages. The change in setule distances during the D. magna life cycle was described by Geller and Muller (1981), suggesting that bacteria may be more important in the juvenile stages than in later stages for this species. Differences in bacterial retention efficiency between young and adult animals were demonstrated by Borsheim and Andersen (1987) in Daphnia longispina.

In the ecossystems, there are cohabiting species with broad and others with narrow feeding niches and, especially in populations composed of different development stages, it is important not to overlap niches. In species with adult fine meshes, such as Daphnia magna, the meshes are almost the same during the body growth. In Daphnia hyalina, however, adults have larger meshes when compared to their adult and juvenile phases and probably can use to feed small particle fractions as they grow (Geller and Muller, 1981). In our study, although the three species have fine meshes, they change differently in each life stages. The $D$. gessneri setules distances increases with the body growth. In C. cornuta the opposite occurs, where there is a reduction of the spacing between the bristles with body growth. In $C$. silvestrii no changes in the distances of setules were found in their different life stages. These differences allow these species to coexist and explore the same environment.

In the environment, the ability of consuming bacteria more efficiently by juvenile stages, as shown in our bacterivory experiments, may reduce competition with their adult counterparts or give them a competitive advantage in relation to other species or life stages, whose meshes 
are less efficient in retaining small particles and bacteria (Brendelberger, 1991).

Concerning the setules bristle width, we observed three distinct patterns. In $D$. gessneri the width on the base and the middle region of the bristle increased with the body size. In C. silvestrii there was a small increase in the median region with the body size of the organism and in C. cornuta, the width decreased from younger adults to older adults. These changes undergone by the cladocerans may be and adaptation to better food capture and can occur in the moulting events. During the moulting process, new bristles are formed inside the old ones. As the new structures are constant in their numbers, their distances necessarily increase with body growth. The setules arising from these bristles, are formed as a whole in the form of fringes. Since the setules are not derived from the previous setules, their number is independent. Thus, as setules numbers may vary from one phase to the other, the distance between them may increase, but not necessarily, with the body growth (Geller and Muller, 1981) or even decrease as found in the present study.

The method used for the bacterivory rates estimations was relatively simple and had the advantage of use an incubation period shorter than the time necessary to bacteria pass through the cladocerans gut ( 2 minutes for $C$. silvestrii and D.gessneri and 4 minutes for C. cornuta), avoiding bias by loss of labeled particles through defecation. In the beginning of the experiment, the increase in the number of labeled bacteria ingested by individual, until reach the maximum and a consequent stabilization, suggests that a balance was achieved between the digestion and / or egestion. The initial slope of the curve provides an estimation of ingestion rates unaffected by loss of the marker through defecation.

The concentration of labeled bacteria used in the experiments was only $5 \%$ of the total bacteria present in the cultivation flasks. At this concentration, the labeled bacteria could easily be quantified and did not significantly change the total bacterial population of the flasks. According to Riccardi (2002), the increase in food concentration can cause a filtration activity reduction in daphnids and can lead to an underestimation in their bacterial removal rates.

The classification into size classes and life stages was important to reduce the variability that can be attributed to variations on intake rates of different sized individuals. Reducing variability is important to obtain more robust and closer to reality results. Beyond the life stage, Lampert (1987) cited several other factors that, direct or indirectly, influence the ingestion and removal rates, such as species, body size, nutritional history, temperature, food quality and quantity.

The differences in removal and intake rates found in our work for the different life stages was also reported by Porter et al. (1983). These differences, in the three species studied, were more important especially for the neonates, which allowed us to infer that the body size of the species alone is not a good indicator of the ability to retain small particles. Studies have shown that cladocerans filtration rates of in some lakes are proportional to their biovolume (Chow-Fraser and Knoechel, 2011). DeMott (1982) attributed the difference between the ingestion rates to species body size, since the incipient limiting level lowers in accordance to the decrease in body size. The theory of optimal foraging for different animal species also predicts that the maximum intake rate should be a function of the volume of the intestinal tract and consequently the body size (Lehman, 1976). In environments with high food concentrations the organisms ingest food until it reaches the so-called incipient limit level, obtained from the maximum removal rate. From this concentration, they perform a precise adjustment of their removal rates just to keep the amount of food obtained constant (Kmet and Straskraba, 2004). The growth of daphnids is affected by the amount of food available depending on the species in question. Bunioto and Arcifa (2007) found that the growth of $D$. gessneri (larger species) is more affected by the concentration of food compared to C. rigaudi (smaller). These authors also noted that $C$. cornuta feeding on small particles, including bacteria, under scarce food availability, has the growth less affected than $D$. gessneri under the same conditions.

We obtained, in the present study, removal rates for neonates of the three tropical and subtropical species higher compared to the rates of the primiparous (Figure 4), this is probably because the adults have wider filtration mesh than young individuals, according to Geller and Muller (1981) and Borsheim and Andersen (1987). Increasing distance between setules with body size only occurred in D. gessneri, while the other two species, in all life stages, had filtration mesh capable of retaining bacteria.

Among the studied species, there was little difference between the ingestion rates found. DeMott (1982) estimated removal values for the Daphinidae family within the range of $13 \times 10^{4}$ to $76 \times 10^{4} \mathrm{~nL}^{-1 d^{-1}} \mathrm{~h}^{-1}$. The values found in our study ranged from $10 \times 10^{4}$ to $38 \times 10^{4} \mathrm{~nL}$ ind $^{-1} \mathrm{~h}^{-1}$. These data support the hypothesis of the minor differences in the feeding behavior of these organisms. It has been suggested by the literature that bacteria are used as a food supplement for cladocerans (Porter et al., 1983), contributing to enhance by $20 \%$ the total carbon incorporation of the body (Wylie and Currie, 1991), and in certain situations, when the algae availability is limited, bacteria can become the main food source (Jürgens, 1994). Since the bacterial phosphorus concentration is generally higher than in algae (Vadstein, 2000), they may represent an important phosphorus source for zooplankton filter feeders (Hessen et al., 2002). As the phosphorus limitation appears to cause a reduction in the algae nutritional value for zooplankton (Gulati and DeMott, 1997), it is possible that the bacterial consumption could help compensate for nutritional deficiencies in the Daphnia diet (Riccardi, 2002). Some authors, such as Wylie and Currie (1991), argue that bacteria play a role as important as algae in the nutrition of zooplankton. Similarly, moderate numbers of bacteria in algal cultures improve the food quality for zooplankton (Vijverberg, 1980). The observed differences in the ingestion and 
removing rates of the species of this study and in their different life stages can be explained by other factors than only the pore mesh of their filtration apparatus. It is possible that other mechanisms than merely filtration may be involved. Among them we can suggest the control of the water volume filtered through the bristles and setules.

\section{Acknowledgements}

We thank CNPq for the financial support (Process $\mathrm{n}^{\circ}$ 475625/2009-9). We also thank Darci C.D. Javaroti, Ana C. Ruela and Henrique C. Alves for the laboratory assistance.

\section{References}

ASSOCIAÇÃO BRASILEIRA DE NORMAS TÉCNICAS ABNT, 2005. NBR 13373: Ecotoxicologia aquática-Toxicidade crônica: Método de ensaio com Ceriodaphniaspp. (Crustacea, Cladocera). Rio de Janeiro: ABNT. 12 p.

AGASILD, H. and NÕGES, T., 2005. Cladoceran and rotifer grazing on bacteria and phytoplankton in two shallow eutrophic lakes: in situ measurement with fluorescent microspheres. Journal of Plankton Research, vol. 27, no. 11, pp. 1155-1174.

ARNOLD, A.E., 1971. Ingestion, assimilation, survival, and reproduction by Daphnia pulex fed seven species of blue-green algae. Limnology and Oceanography, vol. 16, no. 6, pp. 906-920. http://dx.doi.org/10.4319/lo.1971.16.6.0906.

BØRSHEIM, K.Y. and ANDERSEN, S., 1987. Grazing and food size selection by zooplankton compared to production of bacteria and phytoplankton in a shallow Norwegian mountain lake. Journal of Plankton Research, vol. 9, no. 9, pp. 367-379. http://dx.doi.org/10.1093/plankt/9.2.367.

BRENDELBERGER, H., 1991. Filter mesh size of cladocerans predicts retention efficiency for bacteria. Limnology and Oceanography, vol. 36, no. 5, pp. 884-894. http://dx.doi. org/10.4319/1o.1991.36.5.0884.

BUNIOTO, T.C. and ARCIFA, M.S., 2007. Effects of food limitation and temperature on cladocerans from a tropical Brazilian lake. Aquatic Ecology, vol. 41, no. 4, pp. 569-578. http://dx.doi. org/10.1007/s10452-007-9114-2.

CHOW-FRASER, P. and KNOECHEL, R., 2011. Factors Regulating in situ filtering rates of cladocera. Canadian Journal of Fisheries and Aquatic Sciences, vol. 42, no. 3, pp. 567-576. http://dx.doi. org/10.1139/f85-074.

DEBIASE, A.E., SANDERS, R.W. and PORTER, K.G., 1990. Relative nutritional value of ciliate protozoa and algae as food for Daphina. Microbial Ecology, vol. 19, no. 2, pp. 199-210. PMid:24196312. http://dx.doi.org/10.1007/BF02012100.

DEGANS, H., ZOLLNER, E., VAN DER GUCHT, K., MEESTER, L. and JURGENS, K., 2002. Rapid Daphnia-mediated changes in microbial community structure: an experimental study. FEMS Microbiology Ecology, vol. 42, no. 1, pp. 137-149. PMid:19709273. http://dx.doi.org/10.1111/j.1574-6941.2002.tb01003.x.

DEMOTT, W.R., 1982. Feeding selectivities and relative ingestion rates of Daphnia and Bosmina. Limnology and Oceanography, vol. 27 , no. 3 , pp. 518-527.
FREESE, H.M. and MARTIN-CREUZBURG, D., 2013. Food quality of mixed bacteria-algae diets for Daphnia magna. Hydrobiologia, vol. 715, no. 1, pp. 63-76. http://dx.doi.org/10.1007/ s10750-012-1375-7.

GELLER, W. and MÜLLER, H., 1981. The filtration apparatus of Cladocera: filter mesh-sizes and their implications on food selectivity. Oecologia, no. 49, pp. 316-321. http://dx.doi. org/10.1007/BF00347591.

GULATI, R.D. and DEMOTT, W.R., 1997. The role of food quality for zooplankton: remarks on the state-of-the-art, perspectives and priorities. Freshwater Biology, vol. 38, no. 3, pp. 753-768. http:// dx.doi.org/10.1046/j.1365-2427.1997.00275.x.

HAHN, M.W. and HÖFLE, M.G., 2001. Grazing of protozoa and its effect on populations of aquatic bacteria. FEMS Microbiology Ecology, vol. 35, no. 2, pp. 113-121. PMid:11295449. http:// dx.doi.org/10.1111/j.1574-6941.2001.tb00794.x.

HESSEN, D.O., FÆRØVIG, P.J. and ANDERSEN, T., 2002. Light, nutrients, and $\mathrm{P}: \mathrm{C}$ ratios in algae: grazer performance related to food quality and quantity. Ecology, vol. 83, no. 7, pp. 18861898. http://dx.doi.org/10.1890/0012-9658(2002)083[1886:LN APCR]2.0.CO;2.

JÜRGENS, K., 1994. Impact of Daphnia on planktonic microbial food webs: a review. Marine Microbial Food Webs, no. 8, pp. 295-324.

KILHAM, S.S., KREEGER, D.A., GOULDEN, C.E. and LYNN, S.G., 1997. Effects of algal food quality on fecundity and population growth rates of Daphnia. Freshwater Biology, vol. 38, no. 3, pp. 639-647. http://dx.doi.org/10.1046/j.1365-2427.1997.00232.x.

KIM, H.W., HWANG, S.J. and JOO, G.J., 2000. Zooplankton grazing on bacteria and phytoplankton in a regulated large river (Nakdong River, Korea). Journal of Plankton Research, vol. 22, no. 8, pp. 1559-1577. http://dx.doi.org/10.1093/plankt/22.8.1559.

KMET, T. and STRASKRABA, M., 2004. Feeding adaptations of filter feeders: Daphnia. Ecological Modelling, vol. 178, no. 3-4, pp. 313-327. http://dx.doi.org/10.1016/j.ecolmodel.2004.03.008.

LAFORSCH, C. and TOLLRIAN, R., 2000. A new preparation technique of Daphnids for scanning electron microscopy using Hexamethyldisilazane. Archiv für Hydrobiologie, no. 149, pp. 587-596.

LAMPERT, W., 1987. Feeding and nutrition in Daphnia. Memorie dell'Istituto Italiano di Idrobiologia, no. 45, pp. 143-192.

LAMPERT, W., 2006. Daphnia: model herbivore, predator and prey. Polish Journal of Ecology, vol. 54, no. 4, pp. 607-620.

LANGENHEDER, S. and JÜRGENS, K., 2001. Regulation of bacterial biomass and community structure by metazoan and protozoan predation. Limnology and Oceanography, vol. 46, no. 1, pp. 121-134. http://dx.doi.org/10.4319/1o.2001.46.1.0121.

LEHMAN, J.T., 1976. The filter feeder as an optimal forager, and the predicted shapes of feeding curves. Limnology and Oceanography, vol. 2, no. 1, pp. 501-516. http://dx.doi.org/10.4319/ 10.1976.21.4.0501.

PERNTHALER, J., 2005. Predation on prokaryotes in the water column and its ecological implications. Nature Reviews: Microbiology, vol. 3, no. 7, pp. 537-546. PMid:15953930.

PORTER, K.G. and FEIG, Y.S., 1980. The use of DAPI for identifying and counting aquatic microflora. Limnology and Oceanography, vol. 25, no. 5, pp. 943-948. http://dx.doi. org/10.4319/lo.1980.25.5.0943. 
PORTER, K.G. and ORCUTT, J.D., 1980. Nutritional adequacy, manageability, and toxicity as factors that determine the food quality of green and blue-green algae for Daphnia. In: W.C. KERFOOT, ed. Evolution and ecology of zooplankton communities. Hanover: University Press of New England. pp. 268-281.

PORTER, K.G., FEIG, Y.S. and VETTER, E.F., 1983. Morphology flow regimes and filtering rates of Daphnia, Ceriodaphnia and Bosmina fed natural bacteria. Oecologia, vol. 58, no. 2, pp. 156163. http://dx.doi.org/10.1007/BF00399211.

RICCARDI, N., 2002. In situ measurement of Daphnia longispinagrazing on algae and bacteria in a high mountain lake (Lake PaioneSuperiore, Northern Italy) using fluorescently labelled cells. Water, Air, and Soil Pollution, vol. 2, no. 2, pp. 343-357. http://dx.doi.org/10.1023/A:1020183431577.

ROCHA, O., SANTOS-WISNIEWSKI, M.J. and MATSUMURATUNDISI, T., 2011. Checklist de Cladocera de água doce do Estado de São Paulo. Biota Neotropica, vol. 11, pp. 571-592. http://dx.doi.org/10.1590/S1676-06032011000500024.

SHERR, B.F., SHERR, E.B. and FALLON, R.D., 1987. Use of monodispersed, fluorescently labeled bacteria to estimate in situ protozoan bacterivory. Applied and Environmental Microbiology, vol. 53, no. 5, pp. 958-965. PMid:16347355.

SHERR, B.F. and SHERR, E.B., 1991. Proportional distribution of total numbers, biovolume and bacterivory among size classes of 2-20 $\mu$ mnonpigmented marine flagellate. Marine Microbial Food Webs, vol. 5, pp. 227-237.

VADSTEIN, O., 2000. Heterotrophic, planktonic bacteria and cycling of phosphorus: phosphorus requirements, competitive ability, and food web interactions. In: B. SCHINK, ed. Advances in microbial ecology. New York: Kluwer Academic/Plenum Publishers, pp. 115-167.

VIJVERBERG, J., 1980. Effect of temperature in laboratory studies on development and growth of cladocera and copepoda from Tjeukemeer, The Netherlands. Freshwater Biology, vol. 10, no. 10, pp. 317-340. http://dx.doi.org/10.1111/j.1365-2427.1980. tb01206.x.

WYLIE, J.L. and CURRIE, D.J., 1991. The relative importance of bacteria and algae as food sources for crustacean zooplankton. Limnology and Oceanography, vol. 36, no. 4, pp. 708-728. http:// dx.doi.org/10.4319/1o.1991.36.4.0708. 